\title{
i[클
}

\section{The Comparative Study on Internet Banking Usage between Youth and Elderly Population}

\author{
Jay Rakesh Kumar Panwala
}

School of Liberal Studies

\begin{abstract}
.
These days the rapid development of the internet has transformed Internet banking into an elective channel to approach new clients. Banks see the appropriation of virtual banking among youthful grown-ups as another approach to contend with their opponents and increase a more prominent piece of the pie. It is consequently vital for banks to have profound information into the determinants of Internet based financial use. This Research plans to examine and comprehend the Internet banking usage among youth and elderly population and furthermore to realize what influence the utilization of Internet banking administrations. This paper exhibited an observational research, which utilized sample of various age groups just to know use of Internet banking among them. The information is additionally gathered by a questionnaire consisting of relevant question related to the research. The results revealed that convenience, accessibility, security, ease of use, reliability and costs of internet banking tend to influence youth' use of Internet banking. Besides there is differentiating picture between utilization of web banking among old population as there are individuals which agrees with the Convenience, usefulness, security, usability and unwavering quality advantages, which structure a positive effect however there are groups of old individuals who feels there isn't much wellbeing included and hazard factor is high. Such individuals have dread of robbery or fraud and furthermore delay in exercises where there personal data is gathered. There is certain association with understudies' usage of Internet based banking while cost shapes a negative association with the Internet banking use. The discoveries from this venture will help bank officials and showcasing officers to accomplish a superior understanding about there distinctive age group's customers' needs and inclination as for Internet based banking. This will help supervisors of banking partnerships to create powerful showcasing efforts which tailor to the necessities of various age bunch clients so as to advance Internet banking use in this market segment.
\end{abstract}

Keywords: Internet Banking, Virtual Banking 